\title{
CORRELATIVE STUDY OF BACILLARY INDEX WITH HISTOPATHOLOGICAL CHANGES IN VARIOUS FORMS OF LEPROSY
}

\author{
Sudha Smita Rauta1, Chodimella Jaya Raghu Ram², Pullela Venkata Bhaskara Rama Lakshmi \\ ${ }^{1}$ Assistant Professor, Department of Pathology, MIMS, Nellimarla. \\ ${ }^{2}$ Assistant Professor, Department of Pathology, MIMS, Nellimarla. \\ ${ }^{3}$ Professor, Department of Pathology, MIMS, Nellimarla.
}

\section{ABSTRACT}

\section{BACKGROUND}

Leprosy disease or Hansen's disease is a chronic infectious disease caused by bacteria, Mycobacterium leprae which expresses itself in different clinicopathological forms depending upon the immunity of the host. Leprosy was discovered in the year 1873 by G. A. Hansen of Norway.

\section{AIMS}

This work is aimed to study the histopathological variations that occur in various forms of leprosy and to correlate the changes that occur in the tissue with the bacillary index.

\section{METHODS}

Skin biopsies from patients clinically diagnosed as leprosy were received in the Department of Pathology, MIMS, Nellimarla, from January 2014 to January 2016 and this included leprosy patients attending the Dermatology OPD of the hospital. Skin biopsies were obtained after taking informed consent in all cases.

\section{RESULTS}

A total of 60 cases diagnosed as leprosy have been included in the present prospective study. The common age group affected was found to be between 21 to 30 years and the mean age was 38 . This study shows male preponderance to female in the ratio of 1.85:1. Fite-Faraco positivity is $100 \%$ in LL, $75 \%$ in BL and BB and least in TT. Indeterminate leprosy showed highly variable FiteFaraco positivity.

\section{CONCLUSION}

Modified Fite-Faraco technique is the routinely used method to demonstrate mycobacterium leprae in tissue sections. Accurate histological classification is essential for selecting cases for drug trials and the examination of serial biopsies for independent assessment of patient's response to anti-leprosy drugs.

\section{KEYWORDS}

Bacillary Index, Fite-Faraco Stain, Leprosy, Histopathology, Correlation.

HOW TO CITE THIS ARTICLE: Rauta SS, Ram CJR, Lakshmi PVBR. Correlative study of bacillary index with histopathological changes in various forms of leprosy. J. Evolution Med. Dent. Sci. 2016;5(32):1689-1694, DOI: 10.14260/jemds/2016/398

\section{INTRODUCTION}

Leprosy disease or Hansen's disease is a chronic infectious disease caused by bacteria, mycobacterium leprae which expresses itself in different clinicopathological forms depending upon the immunity of the host.[1] Leprosy was discovered in the year 1873 by G. A. Hansen of Norway. ${ }^{[2] ~ I n ~}$ clinical practice, there is no doubt that the histopathological assessment by an experienced pathologist of a representative skin and/or nerve biopsy and enumeration of bacilli provides information as significant as that derived from the clinical examination of the patient.[3]

Ziehl-Neelsen staining method is the old and conventional method of detection of the organism in clinical specimens. ${ }^{[4]}$

Financial or Other, Competing Interest: None.

Submission 27-02-2016, Peer Review 26-03-2016,

Acceptance 01-04-2016, Published 19-04-2016.

Corresponding Author:

Dr. Chodimella Jaya Raghu Ram,

Assistant Professor,

D5, Staff Quarters, MIMS, Nellimarla,

Vizianagaram-535217,

Andhra Pradesh.

E-mail: drjayaraghuram@gmail.com

DOI: 10.14260/jemds/2016/398
Modified Fite-Faraco technique is the routinely used method to demonstrate mycobacterium leprae in tissue sections. Accurate histological classification is essential for selecting cases for drug trials and the examination of serial biopsies for independent assessment of patient's response to anti-leprosy drugs. Many non-lepromatous leprosy patients receiving treatment rapidly lose salient histological features and lesions resolve rapidly and the histological appearances become indeterminate. The pathologist can only report on what he sees and the clinician should accept this limitation and correlate the biopsy report both with the signs he has found on examining the whole patient and with the lepromin results. As a rule, better information will be obtained by taking biopsies of active and more infiltrated lesions than of those which are clinically quiescent or resolving. In view of these factors, I wished to undertake a histological study of some of the patients confronted with this challenging disease which contributes so much to their physical and social disability.

Leprosy is the oldest disease known to the mankind.[5] Leprosy is generally believed to have originated in Asia, the earliest record of Leprosy like disease comes from China and India of 6th century BC. Leprosy in India was first described in the Susrutha Samhita written about 600 BC (Hove) and treatment with Chaulmoogra oil was known at that time. 
Rastogi and Rastogi.[6] quoted the Sanskrit word "Kushta" as the original name for Leprosy in India. The disease was carried from India to Europe in the 4th Century BC by returning soldiers and camp followers from Greek wars of conquest in Asia led by Alexander the great and the earliest description was by Aretaeus in Greece about 150 AD. He called the disease as Elephantiasis. From Greece, Leprosy slowly spread throughout Europe by infected soldiers, traders and settlers.

The earliest evidence of leprosy is seen in Coptic Mummy buried in 5th century AD. Lepromatous leprosy patients are the most important reservoir of infection. ${ }^{[7]}$ In China, the disciple of Confucius named Pau-Niu suffered from lepromatous leprosy, which was known at that time as $\mathrm{Li}$ or Lai. Leprosy constitutes a major public health problem in India with an annual new case detection rate of 0.84 per 10,000 population. [8]

\section{MATERIAL AND METHODS}

Skin biopsies from patients clinically diagnosed as leprosy were received in the Department of Pathology, MIMS, Nellimarla, from January 2014 to January 2016 and this included leprosy patients attending the Dermatology OPD of the hospital. Skin biopsies were obtained after taking informed consent in all cases. The sample size is 60 . Pertinent clinical history like age, duration of lesion, site of lesion, significant family and personal history, occupational history and socioeconomic status were taken and entered in the proforma. After collection of the biopsy specimen, it is processed and histopathological examination is done, sections are stained with Fite-Faraco stain and routine Eosin and Haematoxylin stains.

\section{RESULTS}

In the present study, we compared histological diagnosis of $\mathrm{H}$ and $\mathrm{E}$ sections with a bacillary index of sections stained with modified Fite-Faraco for detecting Mycobacterium leprae in tissue sections skin biopsies of 60 patients, clinically diagnosed as leprosy were studied. M:F ratio in this study is 1.86:1 (Table 1), most patients (25\%) were between 21 to 30 years (Table 2). In present study, 3 patients $(5 \%)$ had a positive family history. In the present study, $40 \%$ of patients are labourers by occupation, $53.3 \%$ patients having a monthly income of $<1000$ rupees. BT and TT being the most common histological type (Table 3 ).

In the present study, $48.3 \%$ showed positive results with Modified Fite-Faraco stain. Fite-Faraco positivity is $100 \%$ in LL (Table 4), $75 \%$ in BL and BB. Fite-Faraco positivity is more in lepromatous cases, the maximum in LL and it is less in tuberculoid cases, least in TT. Indeterminate leprosy showed highly variable Fite-Faraco positivity.

\section{Indeterminate Leprosy}

Five cases have been reported. Most of them showed atrophic epidermis, mild lymphocytic and macrophage accumulation around the neurovascular bundles, superficial and deep dermal vessels, sweat glands and arrector pili muscle (Fig. 1). Focal lymphocytic invasion into the lower epidermis is seen in two cases. One case only gave positivity with Fite-Faraco.

\section{Tuberculoid Leprosy}

Fifteen cases were histologically diagnosed as TT. Histopathological features showed atrophic epidermis, intraneural inflammation, numerous epithelioid cells, many lymphocytes around the granuloma (Fig. 2). Most of the granulomas are composed of central epithelioid cells, large Langhans giant cell, dense peripheral lymphocytic infiltrate. In the majority of cases, the granulomas are seen around the nerve bundles, destroying the architecture and also around the dermal appendages. Two cases showed positivity with Fite-Faraco.

\section{Borderline Tuberculoid}

Fifteen cases have been reported. Histopathology showed atrophic epidermis in 9 cases. Peri appendageal, intraneural inflammation (Fig. 3) in 8 cases, only intraneural in 10 cases. Most of the cases showed numerous epithelioid cells; 8 cases showed Langhans giant cells (Fig. 4). Four cases showed positivity with Fite-Faraco.

\section{Borderline Borderline}

Eight cases were diagnosed histopathologically showed features of normal epidermis, peri appendageal intraneural inflammation, few epithelioid cells, a moderate number of macrophages, few lymphocytes, few plasma cells and macrophagic nerve inflammation (Fig. 5). Six cases showed positivity with Fite-Faraco (Fig. 6).

\section{Borderline Lepromatous}

Four cases have been diagnosed. Histopathological features show two cases with the normal epidermis and two with the atrophic epidermis and numerous macrophages, moderate lymphocytes, few epithelioid cells, few plasma cells were seen. Three cases were positive with Fite-Faraco (Fig. 7).

\section{Lepromatous Leprosy}

Thirteen cases were histologically diagnosed and 9 cases showed atrophic epidermis, two cases intraneural inflammation, 3 cases perivascular and peri-appendage inflammation. All cases showed numerous macrophages, few epithelioid cells and lymphocytes. Most of the cases showed atrophic epidermis, 9 cases showed Grenz zone. Type of nerve inflammation was macrophagic (Fig. 8). All showed positivity with Fite-Faraco (Fig. 9).

\section{Histoid Leprosy}

Seven cases have been reported. Histopathological features show atrophic epidermis and spindled macrophages arranged in a storiform pattern (Fig. 10). All cases showed dense aggregates of spindle-shaped macrophages, six cases showed atrophic epidermis. All cases were positive for FiteFaraco.

\begin{tabular}{|c|c|c|}
\hline Gender & Number & $\mathbf{\%}$ \\
\hline Male & 39 & 65 \\
\hline Female & 21 & 35 \\
\hline Total & $\mathbf{6 0}$ & $\mathbf{1 0 0}$ \\
\hline \multicolumn{2}{|c|}{ Table 1: Gender Distribution of Patients } \\
\hline
\end{tabular}

\begin{tabular}{|c|c|c|c|c|c|c|}
\hline \multirow{2}{*}{ Age in Years } & \multicolumn{2}{|c|}{ Male } & \multicolumn{2}{c|}{ Female } & \multicolumn{2}{c|}{ Total } \\
\cline { 2 - 7 } & No. & $\mathbf{9}$ & No. & \% & No. & \% \\
\hline$<20$ & 03 & 7.7 & 06 & 28.6 & 09 & 15 \\
\hline $21-30$ & 09 & 23.1 & 06 & 28.6 & 15 & 25 \\
\hline $31-40$ & 10 & 25.6 & 03 & 14.3 & 13 & 21.7 \\
\hline $41-50$ & 05 & 12.8 & 04 & 19 & 09 & 15 \\
\hline$>50$ & 12 & 30.8 & 02 & 9.5 & 14 & 23.3 \\
\hline Total & $\mathbf{3 9}$ & $\mathbf{6 5}$ & $\mathbf{2 1}$ & $\mathbf{3 5}$ & $\mathbf{6 0}$ & $\mathbf{1 0 0}$ \\
\hline Mean \pm SD & $\mathbf{4 2 . 6 4 \pm 3 2 . 5 4}$ & $\mathbf{3 0 . 6 7 \pm 1 5 . 2 5}$ & $\mathbf{3 8 \pm 1 6 . 4 8}$ \\
\hline
\end{tabular}




\begin{tabular}{|c|c|c|}
\hline Diagnosis & Number & Percentage \\
\hline Indeterminate & 05 & 8.3 \\
\hline Tuberculoid & 15 & 25 \\
\hline Borderline tuberculoid & 15 & 25 \\
\hline Borderline borderline & 08 & 13.3 \\
\hline Borderline lepromatous & 04 & 6.7 \\
\hline Lepromatous & 13 & 21.7 \\
\hline Total & 60 & 100 \\
\hline \multicolumn{3}{|c|}{ Table 3: Histopathological Diagnosis } \\
\hline
\end{tabular}

\begin{tabular}{|c|c|c|c|}
\hline Diagnosis & $\begin{array}{c}\text { No. of } \\
\text { Patients }\end{array}$ & $\begin{array}{c}\text { No. of } \\
\text { Positives }\end{array}$ & Percentage \\
\hline IL & 05 & 01 & 20 \\
\hline TT & 15 & 02 & 13.3 \\
\hline BT & 15 & 04 & 26.7 \\
\hline BB & 08 & 06 & 75 \\
\hline BL & 04 & 03 & 75 \\
\hline LL & 13 & 13 & 100 \\
\hline Total & $\mathbf{6 0}$ & $\mathbf{2 9}$ & $\mathbf{4 8 . 3}$ \\
\hline \multicolumn{4}{|c|}{ Table 4: Fite Faraco Positivity } \\
\hline
\end{tabular}

\begin{tabular}{|c|c|c|}
\hline Various Studies & Commonest Age & Percentage \\
\hline Present study & $21-30$ & 25 \\
\hline N. Jindal et al.[9] & $21-30$ & 29.45 \\
\hline B. Mehta et al.[10] & $21-30$ & 34 \\
\hline S. M. T. Nardi et al.[11] & $>55$ & 52.3 \\
\hline B. N. Moorthy et al. & $21-30$ & 20.70 \\
\hline \multicolumn{3}{|c|}{ Table 5 } \\
\hline
\end{tabular}

\begin{tabular}{|c|c|}
\hline Various Studies & M:F \\
\hline Present study & $1.86: 1$ \\
\hline N. Jindal et al.[9] & $3.00: 1$ \\
\hline B. Mehta et al.[10] & $2.33: 1$ \\
\hline S. M. T. Nardi et al.[11] & $1.00: 1$ \\
\hline Aryon et al.[12] & $1.46: 1$ \\
\hline B. N. Moorthy et al.[13] & $1.86: 1$ \\
\hline Table 6 \\
\hline
\end{tabular}

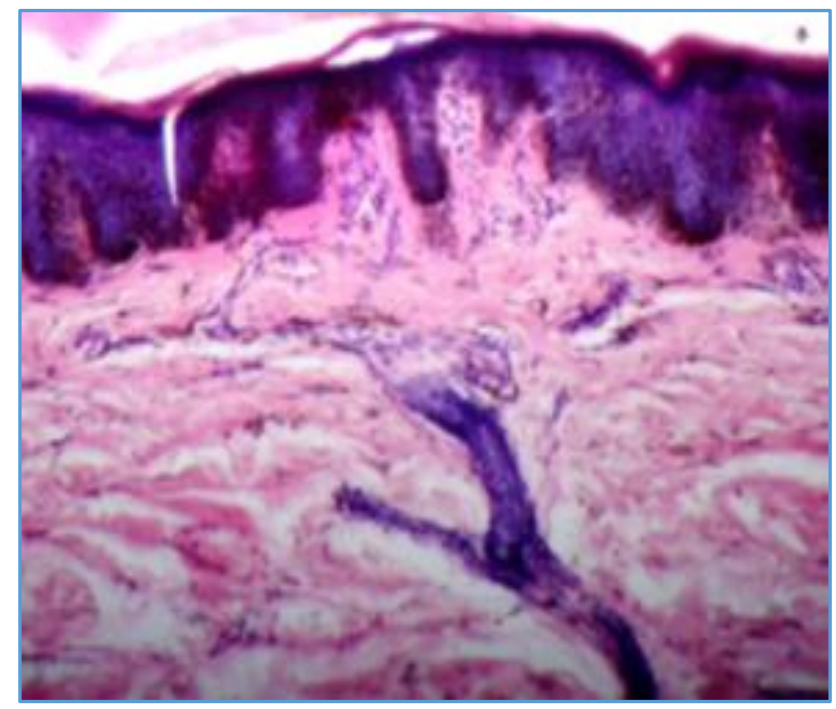

\begin{tabular}{|c|c|c|c|c|c|c|}
\hline Study & $\begin{array}{c}\text { IL } \\
\mathbf{\%}\end{array}$ & $\begin{array}{c}\text { TT } \\
\mathbf{\%}\end{array}$ & $\begin{array}{c}\text { BT } \\
\mathbf{\%}\end{array}$ & $\begin{array}{c}\text { BB } \\
\mathbf{\%}\end{array}$ & $\begin{array}{c}\text { BL } \\
\text { \% }\end{array}$ & $\begin{array}{c}\text { LL } \\
\mathbf{\%}\end{array}$ \\
\hline Present study & 8.3 & 25 & 25 & 13.3 & 6.7 & 21.7 \\
\hline $\begin{array}{c}\text { N. Jindal et } \\
\text { al.[9] }\end{array}$ & 3.16 & 5.7 & 29.1 & 4.43 & 23.4 & 34.2 \\
\hline $\begin{array}{c}\text { B. Mehta et } \\
\text { al.[10] }\end{array}$ & NA & 24 & 29 & 6 & 21 & 20 \\
\hline Aryon et al.[12] & 28.5 & 11.4 & 46.3 & 1.8 & 1.6 & 10.5 \\
\hline $\begin{array}{c}\text { B. Moorthy et } \\
\text { al.[13] }\end{array}$ & 22 & 25 & 53 & 2 & 15 & 19 \\
\hline \multicolumn{7}{|c|}{ Table 7 } \\
\hline
\end{tabular}

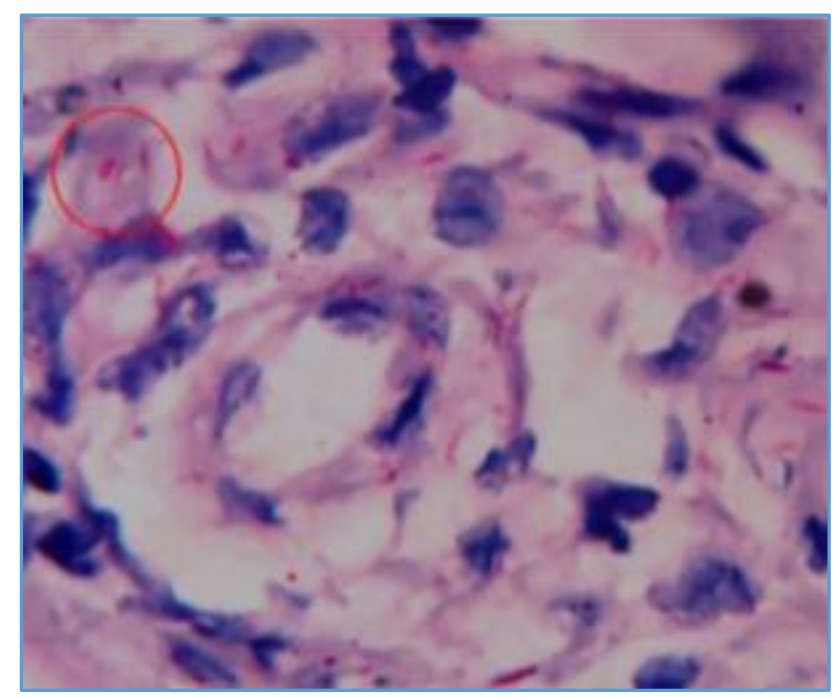

Fig. 1: Indeterminate Leprosy, Mild Peri-Appendageal and Peri-Neural Lymphocytic Infiltrate and Macrophages (100X, H\&E) \& showing Acid Fast Bacilli (1000X, Fite Faraco)

\begin{tabular}{|c|c|}
\hline Various Studies & FF Positive Cases \\
\hline Present study & $29(48.3 \%)$ \\
\hline Nayak et al.[14] & $25(44.64 \%)$ \\
\hline Jariwala et al.[15] & $20(40 \%)$ \\
\hline B. Mehta et al.[10] & $40(40 \%)$ \\
\hline Aryon et al.[12] & $319(56.76 \%)$ \\
\hline \multicolumn{2}{|c|}{ Table 8 } \\
\hline
\end{tabular}

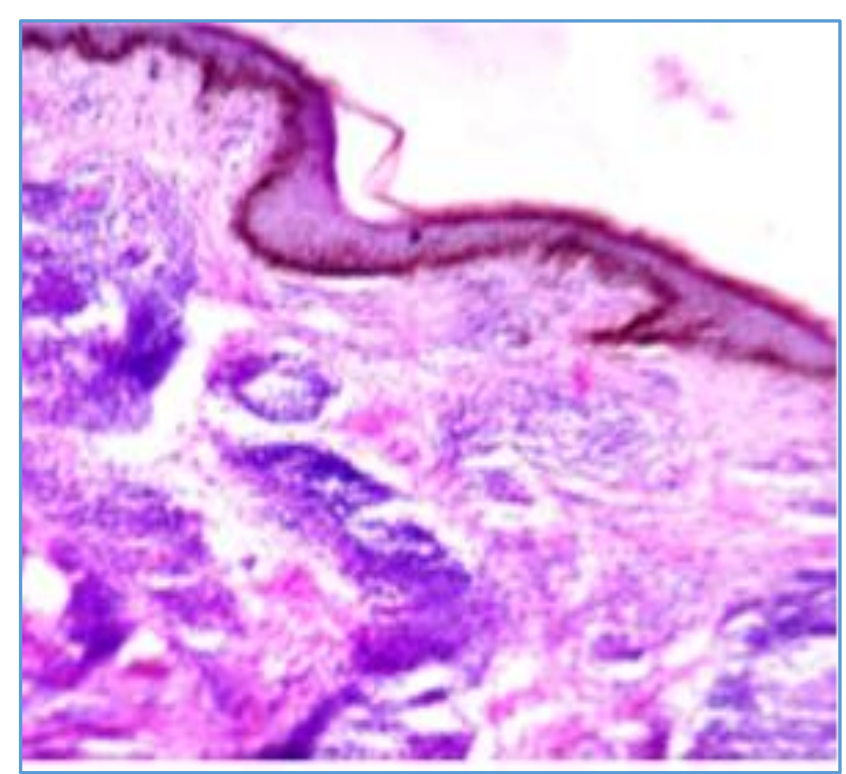




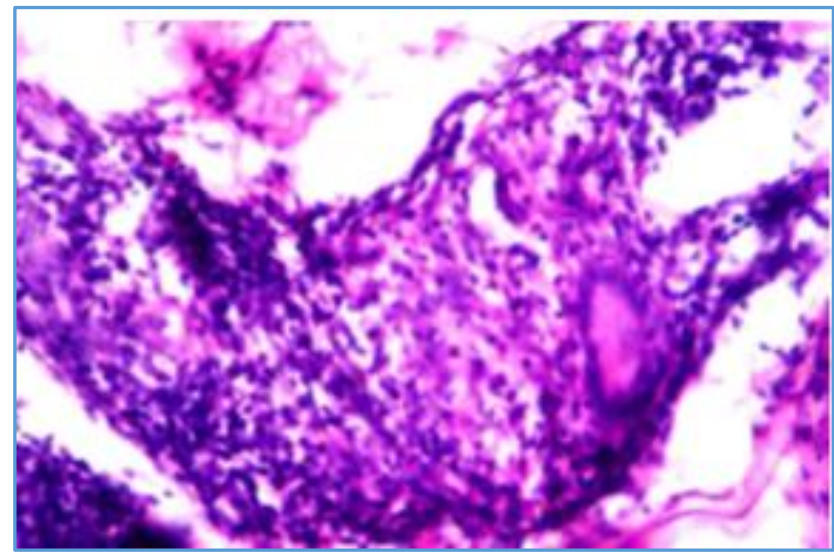

Fig. 2: Tuberculoid Leprosy, Dermal Peri-Appendageal Granulomas Rich in Lymphocytes and Langhans Giant Cell. (100X \&400 X, H\&E)
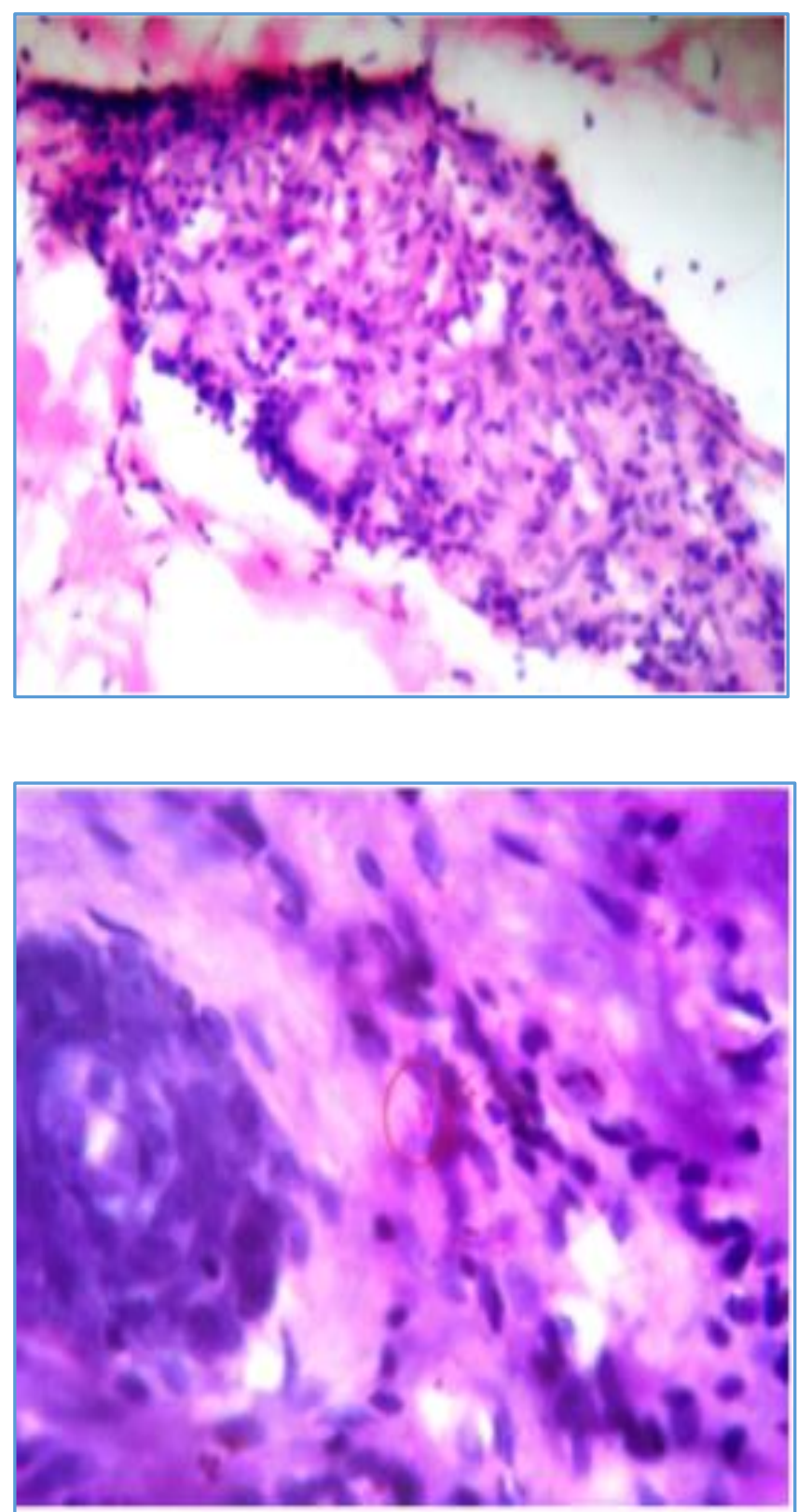

Fig. 3 \& 4: Borderline Tuberculoid, Granuloma formed by Epithelioid Cells, Langhans Giant Cell and Lymphocytes (400X, H\&E) \& Fite-Faraco show Acid Fast Bacilli
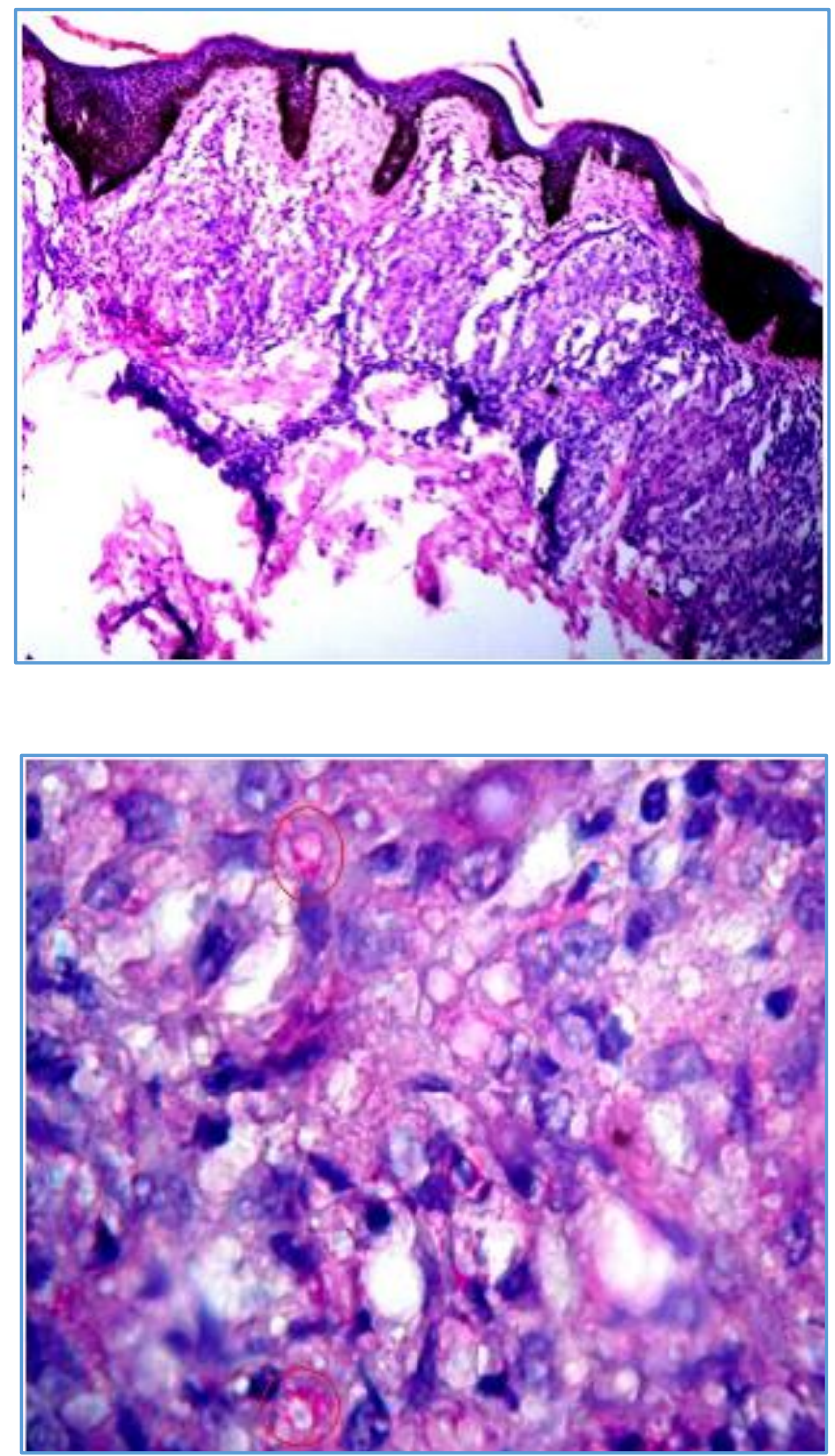

Fig. 5 \& 6: Borderline Leprosy, Plenty of Epithelioid Cells, Macrophages and Few Lymphocytes. (100X, H\&E) \& FiteFaraco show Acid Fast Bacilli

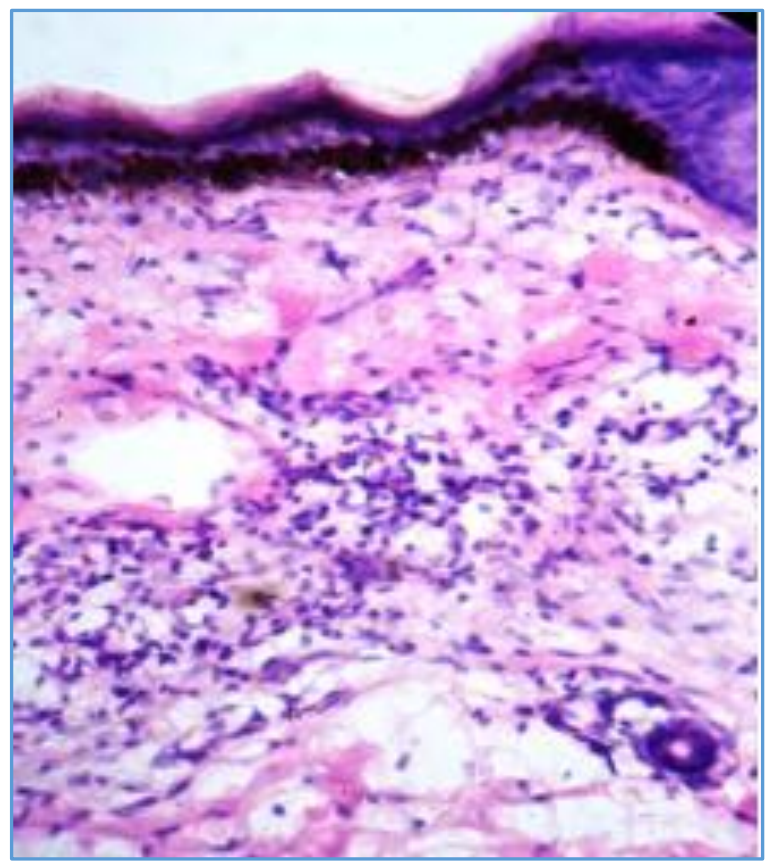




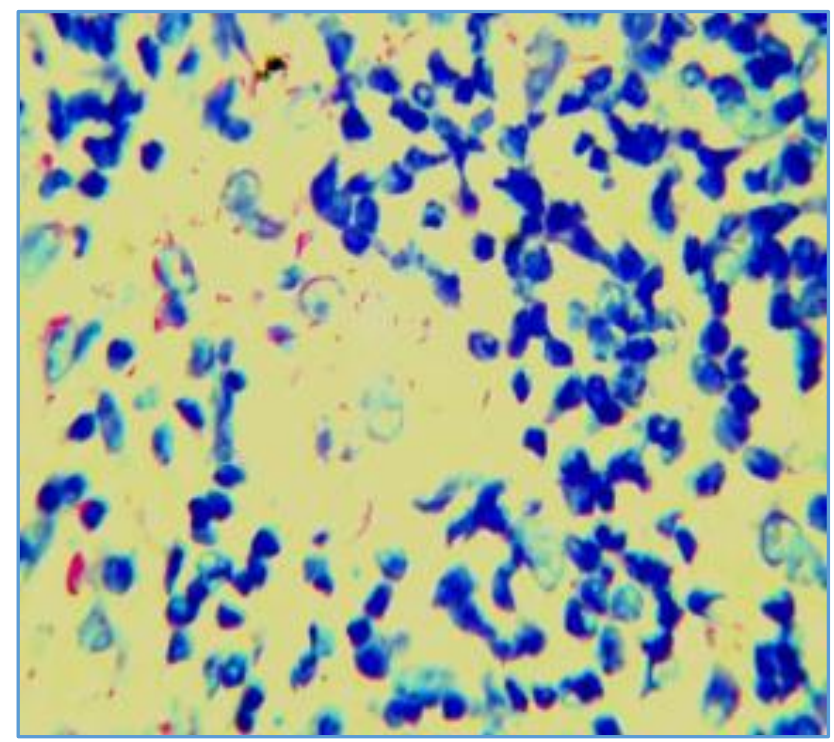

Fig. 7: Borderline Lepromatous showing Macrophages \& Lymphocytes (400X, H\&E) \& Fite-Faraco show Acid Fast Bacilli
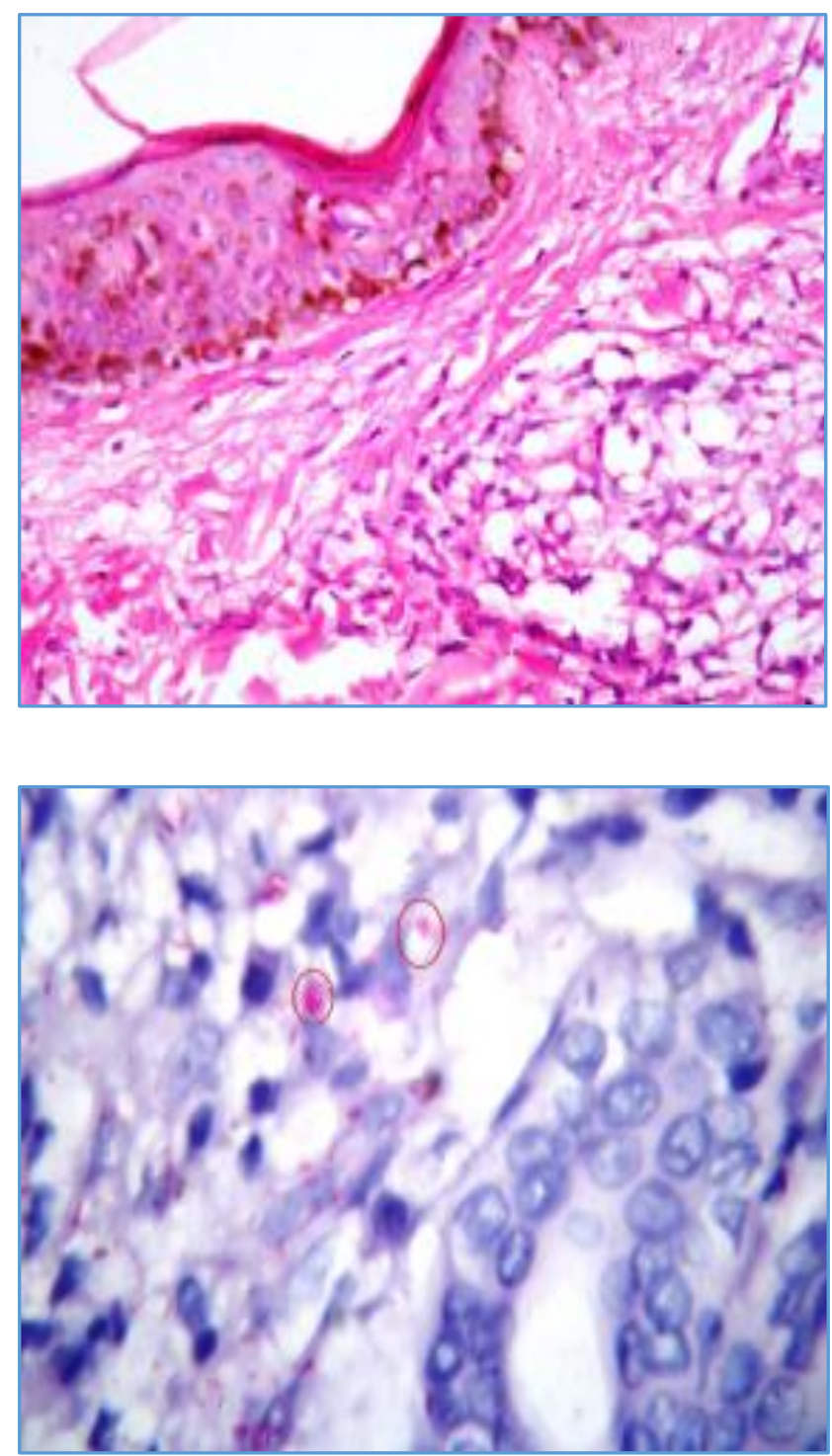

Fig. 8 \& 9: Lepromatous Leprosy, Grenz Zone and Dermal Infiltration of Foamy Macrophages. (400X, H\&E \& Fite Faraco showing Acid Fast Bacilli as Globi
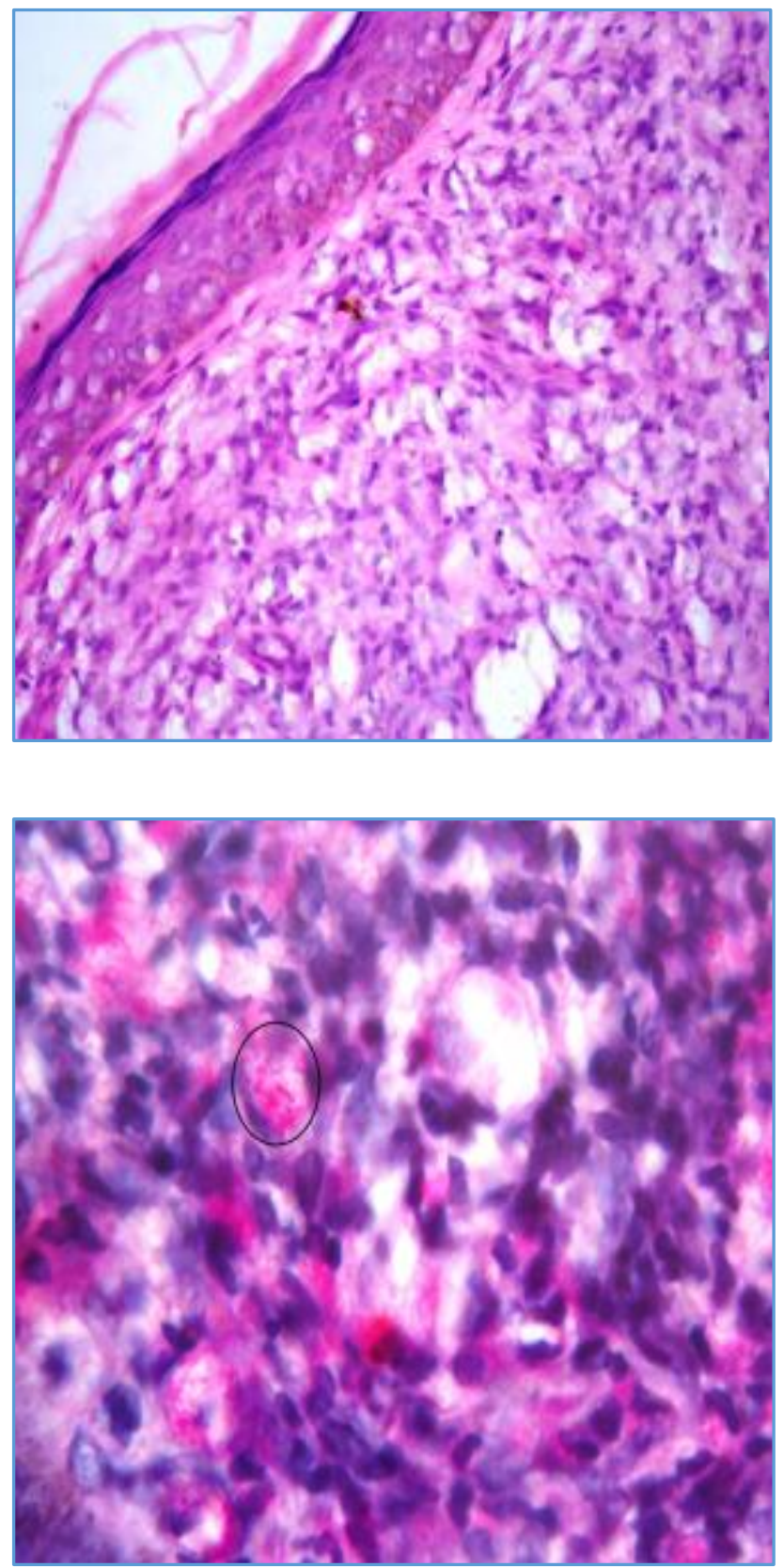
Fig. 10: Histoid Leprosy, Spindle Shaped Histiocytes (400X,
H\&E) \& Fite Faraco showing Acid Fast Bacilli

\section{DISCUSSION}

In the present study, patients in the age group of 21-30 were affected most with 15 cases (25\%). The least affected age group are those who are less than 20 years, comprising 9 cases (15\%). The youngest patient reported is 7 years and the eldest patient reported is $74 \mathrm{yrs}$. The mean age calculated is 38 , the median is 36.5 and the mode is 40 with a standard deviation of 16.48 (Table 5). In the present study, males were affected the most with 39 cases (65\%) and females being 21 cases (35\%) (Table 6). In the present study, the patients were grouped into various categories depending on their occupation.

A number of patients were found to be labourers followed by housewives and agriculturists. In the present study 3 cases (5\%) presented with positive family history, two having contact with grandfather and one with the grandmother. In this study, the patients who are married 
were found to be 53 and unmarried were 7 . Their percentage of the same was $88.3 \%$ and $11.7 \%$ in this study. The selected people are divided into two groups based on their monthly income of less than or more than Rs. 1000 per month. In our study, BT and TT were the most common histological diagnoses (Table 7).

Mean $\mathrm{BI}$ in IL is $0.4, \mathrm{TT}$ is $0.2, \mathrm{BT}$ is $0.7, \mathrm{BB}$ is $1.6, \mathrm{BL}$ is 2 and LL is 4.5 (Table 8).

Chi Square value with Yates correction was done and $\mathrm{p}$ was found to be less than $0.05(\mathrm{p}<0.05)$, i.e. significant.

\section{CONCLUSION}

The Modified Fite-Faraco technique is the routinely used method to demonstrate mycobacterium leprae in tissue sections. Accurate histological classification is essential for selecting cases for drug trials and the examination of serial biopsies for independent assessment of patient's response to anti-leprosy drugs, histopathology of skin biopsy is a simple and economical investigation which plays a crucial role not only in diagnosis but also as an index of patient's response to treatment.

\section{REFERENCES}

1. Abulafia J, Vignale RA. Leprosy pathogenesis updated. Int J of dermatol 1999;38:321-34.

2. Jopling WH, McDougall AC. Definition, epidemiology and world distribution. In: Handbook of leprosy. New Delhi: CBS publishers and distributors, 2005; $5^{\text {th }}$ ed:1-8.

3. Ridley DS, Jopling WH. Classification of leprosy according to immunity. A five-group system. Int J Leprosy 1966;34(3):255-73.

4. Culling CFA, Allison RT, Barr WT. Demonstration methods. In: cellular pathology technique. London: Butterworth and co; 1985; 4th ed:423-540.

5. Browne SG. The history of leprosy. In: Hastings RC, Opromolla DVA, eds. Leprosy. Edinburgh: Churchill Livingstone, $1985 ; 1^{\text {st }}$ ed:1-14.
6. Rastogi N, Rastogi RC. Leprosy in ancient India. Int J leprosy 1984;52:541-3.

7. Noordeen SK. Infectivity of leprosy. Chatterjee BR, edi. A window on leprosy, Calcutta. The Gandhi Memorial Leprosy Foundation, 1978;1st edn:59-63.

8. Park K. Epidemiology of communicable diseases. Park's text book of preventive \& social medicine. Jabalpur, India. M/S Banarasidas Bhanot Publishers; 2009;20th ed:264-78.

9. Jindal N, Shanker V, Tegta GR, et al. Clinicepidemiological trends of leprosy in Himachal Preadesh: a five year study. Indian journal of leprosy 2009;81(4):173-9.

10. Mehta B. Clinic-pathological correlation in leprosy. The internet journal of dermatology 2012;9(1).

11. Nardi SM, Ikehara E, Pedro HS, et al. Characterization of the profession/occupation of individuals affected by leprosy and the relationship with limitations in professional activities. Indian journal of leprosy 2012;84(1):1-8.

12. Aryon de Almeida Barbosa Junior. Retrospective histopathological classification of 1,108 skin biopsies from patients clinically suspected of having leprosy from Bahia, Northeast Brazil. Revista dasociedade Brasileria de medicana tropical 1998;31(6):533-7.

13. Moorthy BN, Kumar $P$, Chatura KR, et al. Histopathological correlation of skin biopsies in leprosy. Indian journal of dermatology, venereology and leprology 2001;67(6):299-301.

14. Nayak SV, Shivarudrappa AS, Mukkammil AS. Role of fluorescent microscopy in detecting mycobacterium leprae in tissue sections. Ann Diagn Pathol 2003;7(2):78-81.

15. Jariwala HJ, Kelkar SS. Fluorescence microscopy for detection of mycobacterium leprae in tissue sections. International Journal of Leprosy 1979;47(1):33-6. 